\title{
Analisis Strategi Mengatasi Stres Kerja Pada Pekerja Wanita di Sentra Industri Pandaan Pasuruan
}

\author{
Andrean Yanwar Krisna ${ }^{1}$, Djoko Kustono ${ }^{2}$, Solichin $^{3}$ \\ 1,2,3 Program Studi S1 Pendidikan Teknik Mesin Jurusan Teknik Mesin \\ ${ }^{1,2,3}$ Fakultas Teknik Universitas Negeri Malang \\ 1,2,3 Jalan Semarang No. 5, Malang 65145 \\ Email: andreanc69@yahoo.com
}

\begin{abstract}
Abstrak: Penelitian ini bertujuan untuk mengetahui seberapa tingkat stres kerja pekerja wanita di sentra Industri Pandaan Pasuruan, serta beberapa penyebab stres kerja pekerja wanita, dan mengatasi stres kerja pekerja wanita. Stres kerja pasti akan dialami oleh seluruh pekerja, penelitian ini bertujuan agar pekerja wanita nantinya lebih diperhatikan dan lebih diperlakukan dengan sewajarnya, tidak melampaui kemampuan dari pekerja wanita itu sendiri. Stres kerja yang terjadi nantinya akan mengurangi tingkat produktivitas dari suatu perusahaan, namun jika pekerja wanita seluruhnya merasa baikbaik saja tanpa tertekan pastinya hasil yang didapatkan juga lebih sempurna dan resiko-resiko lain yang timbul jika mengalami stres kerja nantinya tidak akan terjadi.Penelitian ini merupakan jenis penelitian kuantitatif, karena penelitian ini menggunakan angket. Fokus dari penelitian ini adalah memaparkan secara mendalam atau mendeskripsikan menyeluruh hasil analisis data maupun fakta-fakta yang diperoleh dari pengamatan lapangan oleh peneliti, yang mana peneliti mengambil data penelitian di Sentra Industri Pandaan Pasuruan. Dalam penelitian ini peneliti menggunakan teknik pengambilan data dengan memberikan angket kepada para pekerja wanita sebagai narasumber. Hasil penelitian mengungkapkan bahwa terdapat pengaruh yang signifikan dari (1) perbedaan usia, (2) tingkat pendidikan, (3) pengalaman kerja, (4) jabatan dalam mengatasi stres kerja pada pekerja wanita di Sentra Industri Pandaan Pasuruan. Hal ini ditunjukkan dengan hasil pengujian Regresi dari variabel stres kerja dengan variabel mengatasi stres kerja diperoleh hasil signifikansi sebesar 0,049 lebih kecil dari 0,05.
\end{abstract}

Kata Kunci: pekerja wanita, stres kerja, usia, pendidikan, jabatan, pengalaman

\begin{abstract}
This study aims to find out how the level of work stress of women workers in Pandaan Pasuruan industrial center, as well as some causes of work stress of female workers, and overcome the stress of working female workers. Working stress is sure to be experienced by all workers, this research is aimed at ensuring that women workers will be more cared for and treated more appropriately, not beyond the capabilities of the women workers themselves. Working stress that will occur will reduce the level of productivity of a company, but if all women workers feel okay without the stress of course the results obtained are also more perfect and other risks that arise if experiencing work stress will not happen. This research is a kind of quantitative research, because this research use questionnaire. The focus of this study is to describe in depth or describe thoroughly the results of data analysis and facts obtained from field observations by researchers, which the researchers took research data at the Industrial Center Pandaan Pasuruan. In this study the researchers used the technique of data collection by giving a questionnaire to the female workers as a resource. The results revealed that there were significant influences of (1) age difference, (2) education level, (3) work experience, (4) occupation in overcoming job stress on female workers at the Industrial Center Pandaan Pasuruan. This is indicated by the results of regression testing of work stress variables with variable coping work stress obtained results of significance of 0.049 is smaller than 0.05 .
\end{abstract}

Keywords: female workers, job stress, age, education, position, experience

Pada era perdagangan bebas banyak negara berkembang tidak memberikan perlindungan terhadap hak-hak pekerjanya, tetapi yang terjadi justru banyak pelanggaran terhadap hak-hak pekerja perempuan. Meskipun yang dikenal luas yaitu bahwa pekerjaan perempuan adalah domestic job seperti mengurus pekerjaan-pekerjaan rumah tangga, baik mencuci, memasak, mengerjakan di lingkungan rumah. Sedangkan pekerjaan di luar rumah untuk mencari nafkah dianggap sebagai dunia kaum lakilaki. Tetapi dalam kenyataannya masih banyak dijumpai tenaga kerja perempuan yang bekerja di luar lingkungan rumah, seperti diambil contoh bekerja sebagai karyawan perusahaan.

Pembangunan ketenagakerjaan sebagai bagian integral dari pembangunan nasional berdasarkan Pancasila dan UndangUndang Dasar Negara Republik Indonesia Tahun 1945, dilaksanakan dalam rangka pembangunan manusia Indonesia seutuhnya dan pembangunan masyarakat Indonesia seluruhnya untuk meningkatkan harkat, martabat dan harga diri tenaga kerja serta mewujudkan masyarakat sejahtera, adil, makmur dan merata, baik materiil maupun spiritual.

Kepuasan kerja yang dirasa tak lepas dari suatu keadaan yang mengikuti seorang individu, salah satunya yaitu stress. Sullivan \& Bhagat (1992) menyebutkan bahwa banyak penelitian mengenai pengaruh stres kerja terhadap kepuasan kerja dalam suatu organisasi. Hasil penelitian Alberto (1995), Praptini (2000) menunjukkan bahwa faktor-faktor yang mempengaruhi kepuasan kerja salah satunya adalah stres kerja. Smith (1981) mengemukakan bahwa konsep stres kerja dapat ditinjau dari beberapa sudut yaitu: pertama, stres kerja merupakan hasil dari keadaan tempat kerja. Kedua, stres kerja merupakan hasil dari dua 
faktor organisasi yaitu keterlibatan dalam tugas dan dukungan organisasi. Ketiga, stres karena "work load" atau beban kerja. Keempat, akibat dari waktu kerja yang berlebihan. Dan kelima, faktor tanggung jawab kerja

1. Kesiapan dunia kerja dan dunia industri dalam melaksanakan Work-Based Learning, dilihat dari :
a. Kesiapan pembimbing/instruktur dari industri
b. Kesiapan peralatan/mesin yang ada di DU/DI
c. Kesiapan terhadap jumlah peserta work-based learning
Penelitian ini dinilai memiliki manfaat karena tidak saja mendapatkan temuan empirik-tentang-kesiapan dunia kerja Secara singkat penelitian ini bermanfaat bagi:

a. Bagi Universitas Negeri Malang

Dari hasil penelitian ini diharapkan dapat memberikan masukan dan sumbangan yang berarti bagi Universitas Negeri Malang khususnya Fakultas Teknik Prodi S1 Pendidikan Teknik Mesin.

b. Secara Teoritis

Penelitian ini diharapkan mampu untuk memberikan sumbangan terhadap ilmu wawasan pengetahuan, khususnya bidang K3 Keselamatan Kerja maupun bidang Sumber Daya Manusia dalam kaitannya dengan stres kerja, turn over intention bagi karyawati serta kepuasan kerja.

c. Bagi Peneliti selanjutnya

Penelitian ini diharapkan berguna sebagai acuan bagi peneliti selanjutnya yang memiliki niat untuk memilih melakukan penelitian dengan mengembangkan penelitian ini. Nantinya peneliti selanjutnya dapat melakukan eksplorasi dengan mengembangkan faktor-faktor yang dapat mempengaruhi stres kerja selain yang telah digunakan dalam penelitian ini.

\section{METODE PENELITIAN}

Penelitian tentang analisis strategi mengatasi stres kerja pada pekerja wanita Industri studi kasus pada pekerja wanita di Sentra Industri Pandaan Pasuruan. Di dalam penelitian menggunakan rancangan penelitian deskriptif dengan metode kuantitatif. Penelitian ini bertujuan untuk mengungkapkan serta memaparkan keadaan nyata dari para pekerja wanita yang telah bekerja pada Industri dan selanjutnya menyimpulkannya dalam bentuk laporan sebuah penelitian.

Di dalam penelitian ini peneliti memilih dua variabel, yaitu variabel terikat (dependen), serta variabel bebas (Independent). Di dalam penelitian ini variabel bebasnya yaitu faktor-faktor yang menjadi penyebab stres kerja, dan disimbolkan dengan (x). Variabel-variabel yang dimaksud peneliti meliputi pengalaman kerja, usia, tingkat pendidikan, jabatan. Sedangkan untuk variabel terikat (dependent) dalam penelitian ini yaitu stres kerja yang disimbolkan dengan (y).

Lokasi penelitian yang dijadikan objek penelitian yaitu di Sentra Industri Pandaan Pasuruan. Di wilayah Pandaan Pasuruan memang dapat dikatakan sebagai daerah industri, mulai dari industri tekstil, produksi makanan atau minuman, produkproduk kecantikan, dan sebagainya.

Triangulasi-adalah-teknik pemeriksaan keabsahan data yang memanfaatkan sesuatu yang lain, di luar data itu untuk keperluan pengecekan-atau-sebagai pembanding terhadap data itu. Denzin, 1978 dalam Moleong 2014:330, membedakan empat macam triangulasi sebagai teknik pemeriksaan yang memanfaatkan penggunaan sumber, metode, penyidik dan teori.

Beberapa cara yang dapat digunakan oleh peneliti dalam pengecekan seberapa baik ukuran kepercayaan suatu informasi dapat dilakukan dengan beberapa cara sebagai berikut:

a. Membandingkan hasil dari penelitian berupa dari kuesioner dengan data hasil wawancara.

b. Membandingkan keadaan dan perspektif seseorang dengan berbagai pendapat dan dari sudut pandangan orang lain yang berbeda.

c. Membandingkan hasil wawancara dengan isi dokumen yang berkaitan.

Menurut Arikunto (2002), reliabilitas menunjukkan pada suatu pengertian bahwa instrumen cukup dapat dipercaya untuk digunakan sebagai alat pengumpulan data karena instrumen itu baik. Menurut Siregar (2013) "Reliabilitas adalah untuk mengetahui sejauh mana hasil pengukuran tetap konsisten, apabila dilakukan pengukuran dua kali atau lebih terhadap gejala yang sama dengan menggunakan alat pengukur yang sama pula".

\section{HASIL PENELITIAN}

1. Kesiapan Pada analisis statistik Deskriptif ini, memperoleh penjabaran hasil pengolahan data dari variabel faktor-faktor dari penyebab stres kerja, tingkat usia, tingkat pendidikan, tingkat jabatan serta pengalaman kerja. Pengolahan data dari masingmasing variabel ini menggunakan program komputer yaitu spss windows 22. Berikut ini adalah penjelasan tentang hasil pengolahan masing-masing data.

a. Variabel Usia

Mayoritas responden adalah Karyawati berusia 32-37 tahun yakni senilai 30\% dari seluruh responden. Presentase ratarata stres kerja paling banyak dialami oleh pekerja berusia diantara 26 hingga 31 tahun yakni senilai 78,90 \% dari total seluruh responden, sedangkan untuk nilai rata-rata mengatasi stres kerja paling tinggi didapatkan pada responden/karyawati berusia 26 hingga 31 tahun juga. bahwa untuk nilai paling tinggi usia yang paling banyak 
mengalami stres kerja yakni pada antara usia 26-31 tahun dengan nilai persentase 78,90\%. Usia 26-31 tahun juga mendominasi dengan nilai paling tinggi yakni $77,33 \%$.

b. Variabel Jabatan

Mayoritas responden adalah Karyawati dengan jabatan sebagai pelaksana yakni senilai 66,66\% dari seluruh responden. presentase rata-rata stres kerja paling banyak dialami oleh pekerja berjabatan sebagai pelaksana yakni senilai $60,20 \%$ dari total seluruh responden, sedangkan untuk nilai rata-rata mengatasi stres kerja paling tinggi didapatkan pada responden/karyawati dengan jabatan sebagai pelaksana juga yakni senilai 61,38\%. Nilai paling tinggi usia yang paling banyak mengalami stres kerja yakni pada karyawati berjabatan sebagai Supervisor dengan nilai persentase 64,75\%, untuk para karyawati dengan persentase rata-rata mengatasi stres kerja pada jabatan Pelaksana dengan nilai 61,38\%.

c. Variabel Pendidikan

mayoritas responden adalah Karyawati dengan background pendidikan SMA/K yakni senilai 74,99\% dari seluruh responden. Presentase rata-rata stres kerja paling banyak dialami oleh pekerja dengan background pendidikan SMA/K yakni senilai $60,38 \%$ dari total seluruh responden, sedangkan untuk nilai rata-rata mengatasi stres kerja paling tinggi didapatkan pada responden/karyawati dengan background pendidikan Diploma yakni senilai 61,25\%. Nilai paling tinggi usia yang paling banyak mengalami stres kerja yakni pada karyawati yang memiliki background pendidikan Diploma dengan nilai $61,38 \%$, sedangkan untuk presentasi terbesar karyawati dalam mengatasi stres kerja yakni pada karyawati dengan background pendidikan Diploma pula, dengan nilai persentase sebesar $61,25 \%$.

d. Variabel Pengalaman

Mayoritas responden adalah Karyawati dengan pengalaman kerja kurang dari 1 tahun, atau ( $<1$ Tahun) yakni senilai $52,49 \%$ dari seluruh responden. Presentase rata-rata stres kerja paling banyak dialami oleh pekerja dengan tingkat pengalaman selama 2 hingga 3 tahun yakni senilai 63,26\% dari total seluruh responden, sedangkan untuk nilai rata-rata mengatasi stres kerja paling tinggi didapatkan pada responden/karyawati dengan tingkat pengalaman selama lebih dari 3 Tahun (> 3 Tahun) dengan nilai sebesar $61,05 \%$. Nilai paling tinggi pengalaman yang paling banyak mengalami stres kerja yakni pada karyawati yang memiliki pengalaman kerja selama lebih dari 3 tahun (> 3 Tahun) yakni senilai $61,05 \%$, sedangkan untuk persentase terbesar karyawati dalam mengatasi stres kerja yakni pada karyawati dengan pengalaman kerja selama 2-3 tahun dengan nilai persentase sebesar 63,26\%.

Nilai signifikan tabel ANOVA sebesar 0,049. Artinya nilai signifikan kurang dari 0,05 yang berarti bahwa hubungan bersifat linier. Hal ini menunjukan bahwa terdapat pengaruh yang signifikan dari (1) perbedaan usia, (2) tingkat pendidikan, (3) pengalaman kerja, (4) jabatan dalam mengatasi stres kerja pada pekerja wanita di Sentra Industri Pandaan Pasuruan. Hal ini ditunjukkan dengan hasil pengujian Regresi dari variabel stres kerja dengan variabel mengatasi stres kerja diperoleh hasil signifikansi sebesar 0,049 lebih kecil dari 0,05.

Tingkat Signifikansi menggunakan a $=5 \%(0,05)$. Signifikansi 5\% atau 0,05\% adalah ukuran standar yang sering digunakan dalam penelitian. Nilai signifikansi dari hasil perhitungan SPSS diperoleh nilai Sig sebesar 0,049. Dari hasil perhitungan SPSS diperoleh nilai $F_{\text {hitung }}$ sebesar 3.963

\section{PEMBAHASAN}

Analisis univariant dilakukan dengan tujuan untuk menggambarkan sebaran dari setiap variabel penelitian yang diperoleh secara kuantitatif dengan menggunakan daftar distribusi dan dibuat persentase.

Variabel usia karyawati yang paling banyak mengalami stres kerja yakni pada karyawati berusia diantara 26 hingga 31 tahun, yakni senilai 78,90\%. Berdasarkan usia antara 26 sampai 31 tahun adalah masa-masa dimana karyawati mulai memikirkan atau menjalani berkehidupan baru seperti pernikahan, yang mana jika karyawati bekerja dengan tujuan tersebut, memaksakan diri dengan bekerja terus menerus dan tak sesuai dengan seharusnya yang karyawati kerjakan. Hal tersebut menjadi hal yang paling banyak dialami oleh karyawati di rentang usia 26-31 tahun.

Usia 26-31 tahun juga merupakan usia yang matang untuk bekerja ataupun berkehidupan berkeluarga, jadi misalkan karyawati pada usia tersebut mendapatkan kenaikan jabatan bisa juga menjadikan beberapa karyawati mengalami stres kerja jika karyawati belum merasa sanggup untuk menjalani kegiatan pekerjaan yang tidak sesuai dengan kemampuan mereka.

Otomatis jika jabatan naik, tanggung jawab kerja dari karyawati pasti juga ikut bertambah besar. Dilain pihak, Ford dan Box mengajukan kritik terhadap Musgrave dengan menyatakan bahwa "Dapat dipastikan, bahwa masa transisi dari dunia sekolah ke dunia kerja didalam kasus dimana anak-anak berumur 15 tahun sudah berhenti sekolah tidak dapat diuraikan sebagai suatu proses memilih seccara keseluruha. Anak-anak tersebut tidak tahu tentang keseluruhan masalah pekerjaan yang ditawarkan kepada mereka, dan sama sekali tidak mempunyai criteria untuk membedakan satu pekerjaan dengan pekerjaan loinnya. Dua teori yang terkenal tentang masa memasuki dunia kerja adalah teori Ginzberg dan super, kedua teori itu menyatakan bahwa kita harus menganggap masuknya orang dalam dunia kerja sebagai suatu proses"

Persentase nilai rata-rata mengatasi stres kerja tertinggi diperoleh hasil senilai 77,33\%, yaitu pada rentan usia 26 hingga 31 tahun juga. Disebabkan karena banyaknya tuntutan kehidupan di lingkungan dan di perusahaan yang menjadikan karyawati dengan rentang usia tersebut menjadi lebih terbiasa ataupun lebih berfikir aktif untuk mengatasi stres kerja. 
Stres kerja yang dialami oleh karyawati juga tidak luput dari adanya masalah pada background tingkat pendidikan mereka. Tingkat pendidikan yang rendah, serta tuntutan pekerjaan yang tinggi tidak sesuai dengan kemampuan karyawati sendiri membuat tidak sedikitnya karyawati mengalami stres kerja. Persentase perbedaan tingkat pendidikan dalam mengatasi stres kerja pada rata-rata mengalami stres kerja paling banyak dialami oleh karyawati dengan background pendidikan Diploma dibuktikan dengan nilai persentase sebesar 61,38\%. Karyawati dengan background pendidikan Diploma lebih dominan mengalami stres kerja. Ki Hajar Dewantara (dalam Syarif, t.t:3), pendidikan adalah segala daya upaya untuk memajukan budi pekerti, pikiran serta jasmani anak, agar dapat memajukan kesempurnaan hidup yaitu hidup dan menghidupkan anak yang selaras dengan alam dan masyarakatnya.

Dalam pengertian yang agak luas, Tardif (dalam Syah, 2010:10) mengartikan pendidikan sebagai seluruh tahapan pengembangan kemampuan-kemampuan dan perilaku-perilaku manusia, juga proses penggunaan hampir seluruh pengalaman kehidupan. Karyawati dengan background diploma mengalami stres kerja yang lebih besar diantaranya karena mereka menganggap karyawati dengan background pendidikan dibawahnya seperti SMA/K mendapatkan posisi jabatan yang dapat dibilang terlampau hampir sama.

Hal tersebut juga membuat karyawati berpendidikan diploma seperti merasa diremehkan dari karyawati berpendidikan Sarjana dan merasa ditinggikan sedikit dari karyawati berpendidikan SMA/K. Padahal jika karyawati melanjutkan pendidikan sedikit lagi sudah mampu berpendidikan sebagai sarjana. Selisih jabatan yang lumayan tinggi memungkinkan karyawati berpendidikan Diploma merasa diambang kebingungan (nanggung) pada posisi jabatan yang dimilikinya. Semakin tinggi tingkat pendidikan seseorang maka semakin tinggi juga tingkat produktivitas atau kinerja tenaga kerja tersebut (Simanjuntak,1985).

Perolehan nilai persentase terbesar rata-rata mengatasi stres kerja menurut Gambar 5.2 yaitu pada karyawati berpendidikan Diploma juga, dengan nilai persentase sebesar $61,25 \%$. Banyaknya masalah stres kerja yang dialami karyawati berpendidikan Diploma, menjadikannya terbiasa dan lebih aktif untuk mengatasi stres kerja yang dialaminya. Berbanding terbalik pada karyawati berpendidikan SMA/K ataupun Sarjana, mereka karyawati berpendidikan SMA/K terlampau merasa puas mendapatkan jabatan dan hasilnya yang tidak terlalu terpaut jauh dengan karyawati berpendidikan Diploma. karyawati berpendidikan Sarjana juga beranggapan cukup mendapatkan jabatannya dan hasil sesuai dengan kemampuan yang dimiliki.

Semakin banyak pengalaman yang didapatkan oleh seorang pekerja akan membuat pekerja semakin terlatih dan terampil dalam melaksanakan pekerjaannya (Amron,2009). Pengalaman kerja diperlukan untuk bahan pertimbangan seseorang karyawati atau calon karyawati yang ingin melamar pekerjaan, maupun mencoba keberuntungan lain melamar kerja pada instansi lain. semakin tinggi pengalaman kerja yang dimiliki, maka tidak menutup kemungkinan untuk karyawati merasa siap untuk bekerja dikerasnya Dunia Industri. stres kerja yang paling tinggi dialami oleh karyawati dengan pengalaman kerja selama 2 hingga 3 tahun, yakni dengan persentase sebesar $63,26 \%$. Karyawati dengan pengalaman kerja selama 2-3 tahun biasanya sudah merasa di titik jenuhnya pada pekerjaan. Jika pada awal kerja baru menginjak atau bahkan akan menginjak 1 tahun masa kerja, mungkin dari beberapa karyawati masih merasa tenang dengan kerjanya, sebelum melalui masa-masa selayaknya di masa 2 hingga 3 tahun bekerja.

Persentase rata-rata mengatasi stres kerja paling besar diperoleh hasil pada karyawati dengan pengalaman kerja selama lebih dari 3 tahun (>3 Tahun). Persentase yang diperoleh senilai 61,05\% selisih sedikit dengan pengalaman kerja selama kurang dari 1 tahun (<1 Tahun) yakni senilai 61\%. Pengalaman kerja lebih dari 3 tahun yang menjadikan karyawati lebih paham cara mengatasi stres kerja dibandingkan karyawati dengan pengalaman kerja < 1 tahun. S. Nitisemito (2002:112-113) pada umumnya yaitu:

1. Pengalaman, dengan pengalaman yang lebih banyak diharapkan kemampuan yang lebih tinggi, ide yang lebih banyak dan sebagainya.

2. Tingkat pendidikan, bahwa dengan pendidikan yang lebih tinggi dapat diharapkan pemikiran yang lebih baik. Stres kerja yang dialami oleh karyawati salah satunya juga disebabkan oleh tingkat jabatan. Tingkat jabatan yang dirasa oleh karyawati tidak sesuai dengan kemampuan yang dimiliki oleh karyawati menyebabkan timbulnya rasa khawatir atas hal yang tidak diinginkan seperti hasil tidak sesuai dengan apa yang diharapkan. Menurut Marihot Tua Efendi Hariandja (2002: 156), penempatan pegawai merupakan proses penugasan atau pengisian jabatan atau penugasan kembali pegawai pada tugas atau jabatan baru atau jabatan yang berbeda.Persentase perbedaan tingkat jabatan dalam strategi mengatasi stres kerja diperoleh hasil dengan nilai stres kerja yang paling tinggi yaitu pada jabatan sebagai Supervisor, ditunjukkan dengan nilai persentase sebesar $64,75 \%$. Supervisor memang lebih mendapatkan bagian tugas dengan tingkat tanggung jawab yang tinggi. Beban terasa berat terlebih jika memiliki pekerja asuhannya yang dirasa kurang memiliki kemampuan yang baik, supaya proses produksinya berjalan lancar sesuai dengan standar dan prosedur yang diterapkan oleh pihak perusahaan.

Pada diagram persentase rata-rata mengatasi stres kerja ditunjukkan pada gambar 5.4 yaitu pelaksana, nilai persentase yakni senilai $61,38 \%$. Karyawati dengan jabatan sebagai pelaksana lebih memiliki nilai paling tinggi dalam mengatasi lingkungan kerja bila dibandingkan dengan manager, supervisor, ataupun mandor. Tugas yang diberikan atasan secara terus menerus, dan adanya tuntutan yang harus dilaksanakan dan dikerjakan sesuai dengan yang diinginkan membuat karyawati dengan jabatan pelaksana menjadi lebih mengerti dan lebih sering untuk mencoba mengatasi masalah yang terjadi.

Menurut Schuller dan Jackson (1997:276) mengartikan bahwa penempatan pegawai berkaitan dengan pencocokan seseorang dengan jabatan yang akan dipegangnya berdasarkan pengetahuan, ketrampilan serta kepribadian karyawan tersebut. 
Karyawati berjabatan sebagai pelaksana berinisiatif untuk berusaha bekerja sebaik mungkin juga dengan tujuan menghargai atasan, ataupun bahkan juga menginginkan dirinya untuk mendapatkan kenaikan jabatan.

Menurut Sopiah (2008), terdapat sejumlah penyakit yang disebabkan seseorang mengalami stres yang cukup tinggi serta berkepanjangan, diantaranya adalah penyakit jantung, bisul, tekanan darah tinggi, sakit kepala, gangguan tidur, serta tambah sakit jika menderita sakit. Jika stres akibat kerja tidak dikendalikan dengan baik, dapat mengganggu performasi kerja dan meningkatkan resiko terjadinya kecelakaan kerja, menurunkan produktivitas kerja, serta menyebabkan biaya kompensasi pekerja meningkat (Tarwaka,2010)

\section{KESIMPULAN}

Berdasarkan dari hasil analisa penelitian terhadap hasil yang telah dilakukan maka ditarik kesimpulan sebagai bahan masukan dan pertimbangan dalam kaitannya dengan analisis strategi mengatasi stres kerja pada pekerja wanita Industri, studi kasus pada pekerja wanita di Sentra Industri Pandaan Pasuruan, adalah sebagai berikut:

1. Hasil penelitian mengungkapkan bahwa terdapat pengaruh yang signifikan dari (1) perbedaan usia, (2) tingkat pendidikan, (3) pengalaman kerja, (4) jabatan dalam mengatasi stres kerja pada pekerja wanita di Sentra Industri Pandaan Pasuruan. Hal ini ditunjukkan dengan hasil pengujian Regresi dari variabel stres kerja dengan variabel mengatasi stres kerja diperoleh hasil signifikansi sebesar 0,049 lebih kecil dari 0,05.

a. Perbedaan Usia

Untuk nilai paling tinggi usia yang paling banyak mengalami stres kerja yakni pada antara usia 26-31 tahun dengan nilai persentase $78,90 \%$. Usia 26-31 tahun juga mendominasi dengan nilai paling tinggi yakni $77,33 \%$.

b. Tingkat Pendidikan

Untuk nilai paling tinggi usia yang paling banyak mengalami stres kerja yakni pada karyawati yang memiliki background pendidikan Diploma dengan nilai 61,38\%, sedangkan untuk presentasi terbesar karyawati dalam mengatasi stres kerja yakni pada karyawati dengan background pendidikan Diploma pula, dengan nilai persentase sebesar $61,25 \%$.

c. Tingkat Pengalaman

Untuk nilai paling tinggi pengalaman yang paling banyak mengalami stres kerja yakni pada karyawati yang memiliki pengalaman kerja selama lebih dari 3 tahun (> 3 Tahun) yakni senilai 61,05\%, sedangkan untuk persentase terbesar karyawati dalam mengatasi stres kerja yakni pada karyawati dengan pengalaman kerja selama 2-3 tahun dengan nilai persentase sebesar $63,26 \%$.

d. Tingkat Jabatan

Untuk nilai paling tinggi usia yang paling banyak mengalami stres kerja yakni pada karyawati berjabatan sebagai Supervisor dengan nilai persentase $64,75 \%$, untuk para karyawati dengan persentase rata-rata mengatasi stres kerja pada jabatan Pelaksana dengan nilai $61,38 \%$.

\section{SARAN}

Berdasarkan dari hasil penelitian analisis strategi mengatasi stres kerja pada pekerja wanita Industri, studi kasus pada pekerja wanita di Sentra Industri Pandaan Pasuruan, peneliti memberikan beberapa saran sebagai berikut:

1. Bagi Industri

a. Hasil pengukuran stres kerja tenaga kerja wanita disosialisasikan kepada seluruh pekerja wanita,

b. Serta memberi arahan maupun sosialisasi beberapa pengetahuan tentang apa saja yang dapat mempengaruhi stres kerja dan apa yang akan terjadi nantinya serta cara untuk mengatasinya.

c. Sebaiknya dilakukan antisipasi atau pencegahan tindakan - tindakan yang dapat menyebabkan terjadinya stres kerja. Upaya pencegahan dapat dilakukan misalnya dengan pembentukan organisasi antar pekerja dengan isi seperti Rolling tugas,

d. Saling tegur sapa antar pekerja, membangun lingkungan kerja yang nyaman dengan menambah ventilasi ataupun penerangan maupun alat bantu kerja yang lainnya.

2. Bagi peneliti selanjutnya

a. Dapat melakukan penelitian dengan sampel yang berbeda beserta alat ukur yang beda, atau bahkan sebisa mungkin mengendalikan seluruh faktor - faktor yang mempengaruhi penelitian dengan teknik penelitian serta metode yang berbeda pula.

3. Bagi Jurusan Mesin

a. Penelitian ini selanjutnya dapat dijadikan pertimbangan dijadikan sebagai referensi untuk mengkaji masalah-masalah yang terkait, khususnya jurusan Pendidikan Teknik Mesin Fakultas Teknik Universitas Negeri Malang.

4. Bagi Karyawati

a. Nantinya lebih dapat mengatasi stres yang ada di lingkungan perusahaan, berguna juga untuk mengurangi turn over pada karyawati dengan beban kerja yang berat dan melebihi kemampuan. 
b. Mengadakan acara refreshing tiap tahunnya agar karyawati tidak selalu merasa jenuh dan lebih meningkat dari segi kinerjanya.

Tidak memberikan beban kerja yang terlampau berlebihan serta menciptakan hubungan yang baik antar karyawati agar terciptanya kerja sama yang baik sebagai teamwork.

\section{DAFTAR RUJUKAN}

Arikunto Suharsimi, 2005, Metode Penelitian Kuantitatif. Rosda Karya Bandung

Wexley, N. Kenneth, and Yuki, A. Gary, 2005. Organizational Behavior and Personnel Psychology.Terjemahan oleh Muh. Sobaruddin, Rineka Cipta, Jakarta.

Sugiyono, 2002. Metode penelitian Kuantitatif, Kualitatif dan R\&D. Penerbit, Alfabeta, Bandung.

Slocum M and Hellriegel C, 2007. Technostress in The Workplace Managing Stress in The Electronic Workplace. Journal American Academy of Business.

Singarimbun. 1995. Dasar-Dasar Penelitian Kuantitatif. Salemba Raya. Jakarta

Nogawa, dkk, Three-Shift System Increases Job-Related Strees in Japanese Workers, Journal, 47: 397-404, 2005

Ghozali, Imam, 2001. Aplikasi Analisis Multivariant Program SPSS. Semarang: Badan Penerbit Universitas Diponegoro.

Iswanto, 1999. Manajemen Sumber Daya Manusia, edisi ke-2 Yogyakarta: BPFE

Jalaludin Rahmat, 2004. Metodologi Penelitian Komunikasi, Bandung: Rosdakarya.

Surachmad, Winarno, 1999. Pengantar Metodologi Ilmiah, Dasar, Metode dan Teknik. Edisi ke-4 Bandung : Tarsito

Margiati, L. 1999. Stres Kerja: Latar Belakang Penyebab dan Alternatif Pemecahannya, Jurnal Masyarakat, Kebudayaan, dan Politik, 3 : pp.7180 .

Rini, J.F. 2002. Stres Kerja, Jurnal Team E-Psikologi Jakarta 01.

Siswanti, Y. 2006. Analisis Pengaruh Stres Kerja dalam Memediasi Hubungan Antara Politik Organisasional Dengan Perilaku Agresif, Jurnal Siasat Bisnis, 2 : pp.165-180 Sugiyono. 2003. Statistika untuk Penelitian. CV Alfabeta, Bandung.

Umar, H. 2001. Metode Penelitian untuk Skripsi dan Tesis Bisnis. PT RajaGrafindo Persada, Jakarta. 